\title{
Vascular Endothelial Growth Factor in Acute Lung Injury and Acute Respiratory Distress Syndrome
}

\author{
S. Barratt ${ }^{a, c}$ A.R. Medford ${ }^{b, c} \quad$ A.B. Millar ${ }^{a, c}$ \\ ${ }^{a}$ Academic Respiratory Unit and ${ }^{b}$ North Bristol Lung Centre, ${ }^{c}$ Southmead Hospital, University of Bristol, Bristol, UK
}

\section{Key Words}

Acute lung injury - Acute respiratory distress syndrome . Vascular endothelial growth factor

\begin{abstract}
Acute respiratory distress syndrome (ARDS) is the most severe form of lung injury, characterised by alveolar oedema and vascular permeability, in part due to disruption of the alveolar capillary membrane integrity. Vascular endothelial growth factor (VEGF) was originally identified as a vascular permeability factor and has been implicated in the pathogenesis of acute lung injury/ARDS. This review describes our current knowledge of VEGF biology and summarises the literature investigating the potential role VEGF may play in normal lung maintenance and in the development of lung injury.

๑ 2013 S. Karger AG, Basel
\end{abstract}

\section{Acute Respiratory Distress Syndrome}

The acute respiratory distress syndrome (ARDS) is a form of acute, diffuse, inflammatory lung injury that occurs following damage to the integrity of the alveolar capillary membrane (ACM) and is characterised by the accumulation of proteinaceous non-cardiogenic alveolar oedema, resulting in refractory hypoxaemia. Acutely, the morphological hallmarks are diffuse alveolar damage, with interstitial and alveolar oedema, inflammation and the formation of hyaline membranes [1].

Since the initial description of ARDS by Ashbaugh et al. [2], progress has been made in understanding the pathogenesis of acute lung injury (ALI) $[3,4]$, but little progress has been made in the development of novel therapies. In spite of this, reports suggest that both the incidence and mortality of hospitalised patients are gradually declining, with current mortality rates estimated at $17-23 \%[5,6]$. The reason for this decline in mortality is likely to be multi-factorial, e.g. the introduction of policies to reduce hospital-acquired infections, limiting the use of blood transfusions and the widespread implementation of lowtidal volume, lung-protective ventilatory strategies $[5,6]$.

Survival from ARDS is thought to require renewed integrity of the ACM through the co-ordinated response of several complex molecular processes, including alveolar epithelial type (AE) 2 cell proliferation. Re-absorption of the oedema and clearance of alveolar protein must follow, with eventual normalisation of the alveolar structure, although deficits in respiratory function may persist.

Luyt et al. [7] recently compared long-term outcomes of survivors of pandemic H1N1 influenza-associated severe ARDS using extracorporeal lung assistance need as a surrogate ARDS severity marker. One year after intensive care unit discharge, 50 and $40 \%$ of patients with and without extracorporeal lung assistance, respectively, reported significant exertional dyspnoea, with 75 and $64 \%$ of patients demonstrating decreased diffusion capacity

\section{KARGER}

E-Mail karger@karger.com

www.karger.com/res
(C) 2013 S. Karger AG, Basel

0025-7931/13/0874-0329\$38.00/0
Dr. Andrew R.L. Medford

North Bristol Lung Centre

Southmead Hospital

Westbury-on-Trym, Bristol, BS10 5NB (UK)

E-Mail andrewmedford@ hotmail.com 
despite minor CT abnormalities with near-normal and comparable lung function tests.

Some patients do not resolve their lung injury, however, and progressive fibrin deposition occurs with the development of lung fibrosis. This fibroproliferative phase of ARDS may occur as early as within the first $24 \mathrm{~h}$ of the predisposing insult $[8,9]$. The biological processes that determine why a patient may survive with complete radiological resolution, survive with residual pulmonary fibrosis or succumb to this syndrome are not currently fully understood.

Vascular endothelial growth factor (VEGF) is a glycoprotein originally isolated as a permeability factor [10]. Whilst being critically important to organogenesis [11, 12], high levels of VEGF persist in the lungs in adulthood; indeed, of all the organs, the lungs are the most predominant source of VEGF in adults $[13,14]$. These factors have led many, including our group [15], to consider that VEGF may play a role in both normal lung maintenance and in the pathogenesis of ARDS.

This review summarises our current understanding of VEGF biology, how it may contribute to the maintenance of the healthy lung and finally how changes in VEGF bioavailability may contribute to the pathogenesis of ARDS.

\section{VEGF Biology}

VEGF-A (VEGF hereafter) is a $34-$ to $46-\mathrm{kDa}$ disulphide-linked dimeric glycoprotein belonging to a superfamily of VEGF-related proteins that includes VEGF-B, VEGF-C, VEGF-D, VEGF-E and placental growth factor (PlGF) [16].

VEGF was originally isolated as a permeability factor [10] but was subsequently shown to have additional potent mitogenic and angiogenic properties $[10,17,18]$. It is essential for normal organogenesis and angiogenesis in both humans and animals, where deletion of a single allele has been associated with lethality in mice $[11,12]$.

Six human VEGF mRNA variants exist $\left(\mathrm{VEGF}_{121}\right.$, $\mathrm{VEGF}_{145}, \mathrm{VEGF}_{165}, \mathrm{VEGF}_{183}, \mathrm{VEGF}_{189}$ and $\mathrm{VEGF}_{206}$ ), which are formed by alternative splicing of VEGF mRNA at exons 6 and 7. The isoforms subsequently formed, collectively termed the VEGF $\mathrm{xxx}_{\mathrm{x}}$ isoforms, differ in the number of amino acids in the resulting protein (denoted by the subscript number) [19]. The isoforms have varied heparin-binding affinities: $\mathrm{VEGF}_{121}$ lacks both exons 6 and 7 and is the most freely diffusible isoform. $\mathrm{VEGF}_{189}$ and $\mathrm{VEGF}_{206}$ are almost completely sequestered in the extracellular matrix where they may act as a reservoir of
VEGF, released by heparinases or proteolytic enzymes, such as plasmin $[20,21]$. VEGF 165 is the most extensively studied isoform and is considered to be the most biologically active. Lacking exon 6 but not exon 7 , it has intermediate heparin-binding properties with $50 \%$ being freely diffusible [20].

A second family of VEGF isoforms is thought to exist, the $\mathrm{VEGF}_{\mathrm{xxx}} \mathrm{b}$ isoforms, formed by differential splicing of the VEGF gene, $66 \mathrm{bp}$ distal to the conventional splice acceptor site in exon 8 (termed exon $8 \mathrm{~b}$ ). The resulting proteins correlate with the expected molecular masses for common $\mathrm{VEGF}_{\mathrm{xxx}}$ isoforms but differ by an alternative terminal 6 amino acids: Ser-Leu-Thr-ArgLys-Asp (SLTRKD) instead of Cys-Asp-Lys-Pro-ArgArg (CDKPRR) in VEGF $\mathrm{xxx}_{\mathrm{xx}}$ isoforms [22]. The carboxylterminal domain of VEGF has been shown to be necessary for determining mitogenic potency [23] and as such VEGF $_{165} b$, the most widely studied of the $V_{E G F}$ xxx isoforms, has been shown to be functionally different from $\mathrm{VEGF}_{165}$. It inhibits $\mathrm{VEGF}_{165}$-induced endothelial cell (EC) proliferation and migration in vitro, arterial vasodilatation ex vivo and angiogenesis in vivo [22, 24]. For these reasons, the $\mathrm{VEGF}_{\mathrm{xxx}} \mathrm{b}$ isoforms have been termed 'inhibitory or anti-angiogenic' isoforms.

Whilst VEGF is the most widely studied molecule of the VEGF gene family, other family members may form heterodimer complexes with VEGF [25], which can then competitively bind to VEGF receptors (VEGFRs) to modulate signalling $[25,26]$.

VEGF-B is predominantly expressed in the heart [27] and exerts its biological effects through VEGFR1 $[25,28]$ and neuropilin (NRP) 1 [29]. Unlike other VEGF family members, it does not appear to have a prominent role in developmental angiogenesis $[11,12,30]$, but rather in blood vessel survival and growth under pathological conditions [31]. It has also been reported to contribute to the pulmonary vascular remodelling observed in the development of chronic hypoxic pulmonary hypertension in mice [32], although this was not confirmed by other studies [33].

Sharing sequence homology [34], VEGF-C and VEGF$\mathrm{D}$ are both primarily associated with angiogenesis and lymphangiogenesis [35], signalling through VEGFR-2 and VEGFR-3 [26, 36]. At high concentrations, both VEGF-C and VEGF-D are also reported to act as vascular permeability factors [37]. Furthermore, tumour expression of VEGF-C and VEGF-D has been correlated with clinico-pathological features of various human cancers, including metastatic spread [38].

VEGF-E is an Orf virus-encoded VEGF, which binds specifically to VEGFR-2 [39]. Although this molecule has 
Fig. 1. Schematic diagram of the VEGF receptors and co-receptors. VEGFR1 and VEGFR2 are structurally related tyrosine kinase receptors that bind VEGF-A with different affinities. They are composed of 7-immunoglobulin-like domains (circles), a single transmembrane spanning domain, a split intracellular kinase domain (rectangles) and a C-terminal tail carrying several tyrosine kinase residues involved in downstream signalling. The NRP1 and NRP2 receptors consist of 5 extracellular domains. B1/B2 domains (circles) bind directly to VEGF molecules. They have a short intracellular cytoplasmic tail and thus were historically thought to lack intrinsic catalytic function.

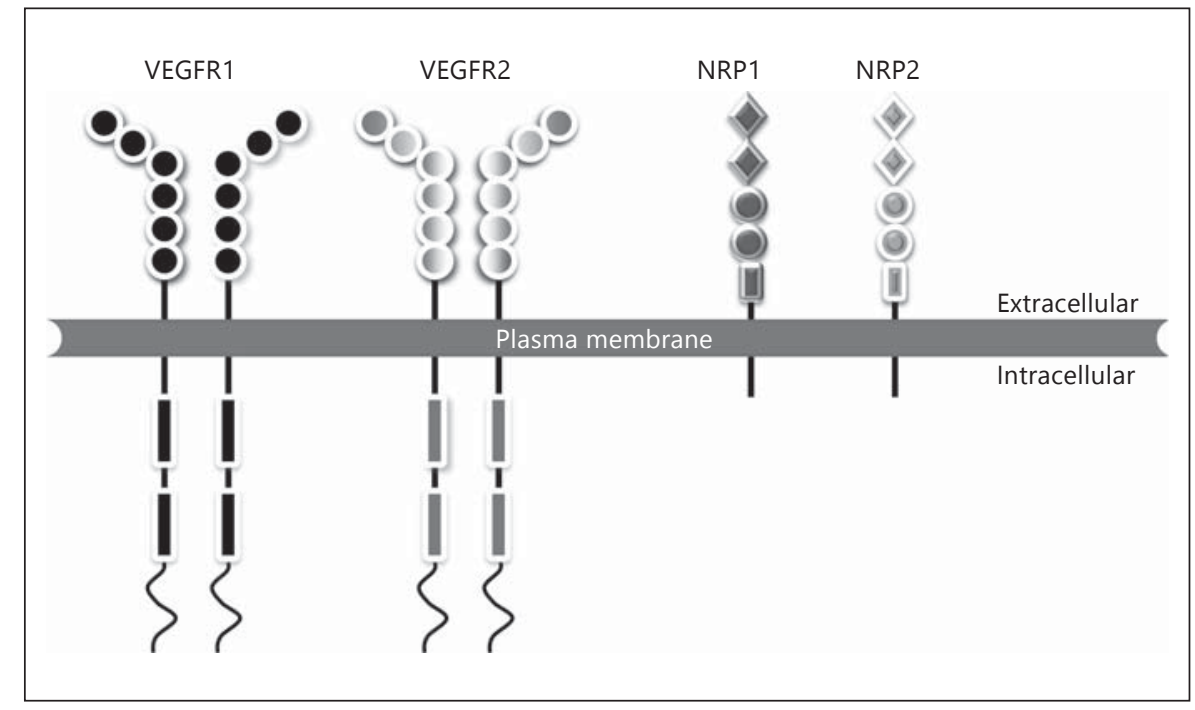

not been widely studied, evidence suggests that it can act as an EC mitogen and permeability factor with similar potency to that of VEGF $_{165}$ [39].

PlGF is expressed in several tissues, including the lung [40], and specifically binds to VEGFR1 [41]. Its role as an angiogenic and permeability factor within the systemic vasculature is well established [42]. Studies have also suggested a potential role for PlGF in the pathogenesis of emphysema [43] and in the pulmonary adaptive response to hypoxia [44].

\section{VEGFR1 and VEGFR2}

VEGF binds to three highly related tyrosine kinase receptors, VEGFR1, VEGFR2 and VEGFR3 characterized by 7 immunoglobulin-like extracellular domains with an intracellular split-kinase region (fig. 1). VEGFR3 expression is predominantly restricted to the lymphatic system [45] and is therefore not discussed further in this review.

VEGFR2 or kinase domain region (KDR)/fetal liver kinase-1 (Flk-1) is a 210- to $230-\mathrm{kDa}$ glycoprotein that is considered by many as the main signalling receptor for VEGF bioactivity [46, 47]. Traditionally, VEGFR2 was thought to be exclusively expressed by ECs with highest expression levels during embryonic vasculogenesis and angiogenesis $[48,49]$, where it is critical to normal vascular development [50]. Subsequently, it has been shown that VEGFR2 is expressed on both sides of the ACM by a variety of cells, including lung macrophages [16] and AE2 cells [51].

The related VEGFR1 [or Fms-like tyrosine kinase 1 (Flt-1) in the mouse] is a 180 - to $185-\mathrm{kDa}$ receptor tyro- sine kinase glycoprotein [52] that binds to VEGF at sites distinct to those of VEGFR2 [23].

It was initially believed that VEGFR1 was largely confined to vascular endothelium throughout development and in adulthood [53], but has subsequently been detected in a wide range of non-ECs both in the lung and elsewhere in the body, such as in glomerular ECs [54], monocytes, macrophages [55] and AE2 cells [56].

The precise role of VEGFR1 and its alternatively spliced, soluble form (sFlt1), remains unclear, but an abundance of evidence supports a negative regulatory role on VEGF bioactivity, acting as a decoy or silent receptor to sequester VEGF from VEGFR2 binding [57, 58]. Supporting this theory, both VEGFR1 and sFlt-1 bind to VEGF with higher affinity than VEGFR2 $[53,59]$ but induce only weak intracellular tyrosine kinase activity [60].

However, more recent evidence disputes the theory of VEGFR1 as a silent receptor. Zhang et al. [61] suggest that VEGFR1 activation is essential for growth and survival of human dermal ECs, whilst Kanno et al. [62] have implicated VEGFR1 in EC actin reorganization and migration.

\section{Co-Receptors: NRP1 and NRP2}

NRP1 and NRP2 are 130-kDa proteins that were originally identified as receptors for semaphorins: important growth factors for axonal guidance in neural development [63-65]. Subsequently, it was found that the NRPs also function as VEGF isoform-specific receptors, binding $\mathrm{VEGF}_{165}$ with the highest affinity [66]. 
The primary structure of the NRPs is well conserved (44\% primary structure homology) [64] (fig. 1). Importantly, however, they differ at the point where VEGF binds to the receptor (within the b1 domain) and consequently VEGF binds to NRP2 with approximately a 50fold lower affinity than to NRP1 [67].

Both NRP1 and NRP2 receptors have been identified on several cell types, including on both sides of the ACM: AE2 cells [68], adult ECs [66], by several tumour cell lines [69], stem cells [70], neuronal cells [71] and by lung cancer cells [72].

NRPs have a short intracellular domain and as such complex formation with a co-receptor has been deemed necessary for signal transduction $[73,74]$. Functioning as a co-receptor, NRP1 has been shown to augment the binding of VEGF 165 to VEGFR2 when co-expressed on the same cell, enhancing $\mathrm{VEGF}_{165}$-mediated proliferation and migration [66]. More recent data suggest, however, that NRP1 may function independently in the maintenance of the normal alveolar structure [75] as NRP1-deficient mice display de novo pulmonary abnormalities. Furthermore, enhanced airspace enlargement and epithelial apoptosis were observed in response to chronic cigarette exposure compared to control mice.

\section{VEGF in Lung Maintenance}

As previously mentioned, of all the organs, expression of VEGF mRNA in adulthood is highest in the lung in both animals and in humans $[13,14]$. In the healthy human lung, VEGF levels are highly compartmentalised, with alveolar protein levels 500 times higher $(2 \mathrm{nM})$ than plasma levels [76]. These levels are also twice those previously shown to induce permeability and mitogenesis in vivo [77], and yet in the normal lung these processes are extremely limited. This implies a persistent role for VEGF in the adult lung that extends beyond its critical role in development.

The alveolar epithelium is considered to be the predominant source of VEGF in the lung $[14,56,76]$, although other cells, such as smooth muscle cells, macrophages, and ECs, also express VEGF [78, 79]. Likewise, VEGFR and co-receptors are expressed on both sides of the ACM [68].

Although AE2 cells are thought to be the main source of VEGF [76], the physiological role of VEGF generated from this source remains unclear [76]. It has been proposed that it may function as a survival factor for both epithelial cells [80,81] and ECs [82] in the normal lung, possibly acting in an autocrine fashion on epithelial cells [81] and modulating the functions of the adjacent vascular endothelium in a paracrine manner [83]. The VEGF survival signal in both ECs and epithelial cells is in part mediated through the phosphatidylinositol 3-kinase/Akt signal transduction pathway $[81,82]$.

In a model of mechanical alveolar cell over-distension, VEGF also influenced epithelial cell survival [84]. In this model, high-amplitude mechanical stretch induced secretion of VEGF from rat AE2 cells grown in vitro which at high concentrations inhibited stretch-induced apoptosis of these cells.

Whilst the ability of VEGF to induce proliferation of the systemic vasculature is well established [85], studies have also suggested that VEGF can stimulate growth of AE2 cells in vitro [86] and surfactant production [87].

Furthermore, VEGF promotes EC expression of the anti-apoptotic proteins $\mathrm{BCl}-2$ and $\mathrm{A} 1$ [88], whilst additionally blocking EC apoptosis mediated through the surface 'death receptors' TNF receptors and Fas [89]. To date, few studies have investigated the effect of VEGF on lung epithelial cells, but limited evidence from in vitro studies suggests that at high concentrations VEGF may also inhibit AE2 apoptosis $[84,86]$.

Animal studies using adenoviral vector-mediated, lung-targeted ablation of the VEGF gene resulted in apoptosis of alveolar septal wall cells and the development of an emphysema phenotype in mice, providing corroborative evidence that VEGF in AE2 cells contributes to alveolar epithelial cell survival and lung maintenance [90]. Likewise, targeted deletion of VEGF in distal lung epithelial cells (SPC-VEGF-KO mice) also resulted in the development of emphysema-like pathological findings with an increase in activated caspase-3-positive AE2 cells [91].

VEGFR2 signalling appears central to lung maintenance in vivo, as chronic VEGFR inhibition resulted in alveolar septal cell apoptosis and emphysema, associated with a reduction in VEGFR2 expression and phosphorylation [92, 93]. Furthermore, mesenchymal stem cell (MSC) administration improves emphysema induced by cigarette smoke exposure in rats, mediated in part through up-regulation of VEGF and VEGFR2 [94].

Whilst these studies suggest that VEGF is important for lung maintenance, it is apparent that expression levels are tightly regulated in the normal lung since conditional over-expression of VEGF in respiratory cells also causes an emphysema-like phenotype in adult mice [95]. Moreover, lung-targeted $\mathrm{VEGF}_{165}$ transgenic mice develop pulmonary neovascularisation and increased vascular permeability [96]. 
These studies suggest that following development VEGF assumes a role in normal lung homeostasis and in these circumstances the respiratory epithelium may provide a potential physiological reservoir of VEGF. A healthy ACM, compartmentalising VEGF, may be crucial to this process [76]. If the integrity of the ACM is breached, as occurs in ALI/ARDS, VEGF may reach the EC at high levels, inducing increased vascular permeability and pulmonary oedema $[15,76]$.

\section{Role of VEGF in ALI/ARDS}

To date, the majority of research exploring the role of VEGF in the lung has focused on the VEGF-A molecule. There are numerous apparently conflicting reports of VEGF acting as a pathological or protective factor in ALI/ ARDS, which are discussed below.

VEGF-C has been implicated in the modulation of innate and adaptive immune responses in the development of chronic inflammation associated with experimental obliterative airway bronchiolitis [97], but investigation into its potential role in ALI/ARDS has not been addressed.

\section{VEGF Genetic Polymorphisms in ALI/ARDS}

There is growing evidence to suggest that genetic factors may play a role in the development of lung injury. We have previously reported on the presence of a genetic polymorphism (VEGF +936), associated with lower broncho-alveolar lavage fluid levels of VEGF, which is frequently present in patients with ARDS and associated with higher APACHE III scores [98, 99].

In a case-control study, this VEGF +936 polymorphism was also present at significantly higher frequency in Chinese patients with ARDS than in controls (odds ratio $=3.85, p=0.04)$ and was associated with increased mortality (odds ratio $=5.72, \mathrm{p}=0.03$ ) [100].

Other genetic variations in the VEGF pathway have also been implicated in the development of ALI/ARDS. Single nucleotide polymorphisms (SNPs) in VEGFR1 and in downstream mediators of the VEGF signalling pathway (e.g. RAF1 and NRAS) were consistently associated with the risk of pulmonary complications, which included ALI and ARDS, following lobectomy, but the exact functional significance of these SNPs has yet to be determined [101].

VEGF genetic polymorphisms (SNPs rs10434 and rs3025028) have also been implicated in the genetic determination of airway function from birth to adulthood.
The functional significance of SNP rs3025028 polymorphism has also been linked to alterations in ratios of plasma VEGF ${ }_{165}$ b to VEGF ${ }_{165}$ a in several cohorts [102].

\section{VEGF in the Exudative Phase of ALI/ARDS}

Early ARDS is characterised by increased vascular permeability with exudation of proteinaceous fluid and migration of inflammatory cells from the vascular compartment into the interstitium and alveolar space.

\section{Human and Cellular Studies}

To date, the majority of human studies have shown a reduction in intrapulmonary VEGF in early ARDS with an associated rise in VEGF plasma levels [103-105] and normalization of both during recovery $[103,105]$.

The observed reduction in intrapulmonary VEGF in early ARDS may be explained by a number of hypotheses. Firstly, as a prominent source of VEGF, direct injury to and clearance of AE2 cells may significantly reduce the cellular production of VEGF. In support of this hypothesis, a reduction in AE2 cellularity due to apoptosis has been observed in ARDS [106], which may be mediated in part through the release of Fas ligand [107]. Contradicting this theory, however, Tuder et al. [108] reported a decrease in VEGF mRNA after intraperitoneal injection of lipopolysaccharide (LPS) in rats, a model in which epithelial injury does not occur.

It has also been speculated that these changes may be due to the degradation of VEGF by proteases and inflammatory cells in the alveolar space $[105,109]$.

Another possible explanation for the intrapulmonary reduction in VEGF includes differential splicing of the VEGF gene, producing less soluble and more membranebound isoforms. We have explored this hypothesis and have shown a lower ratio of soluble/cell-associated isoforms in early ARDS compared to normal and late ARDS patients, and this was also true in murine lung injury [110]. For instance, the soluble $\mathrm{VEGF}_{121}$ isoform is unable to form complexes with membrane-bound heparin sulphate proteoglycans [20]. These proteoglycans are considered cofactors for VEGF signalling that are thought to stabilise the ligand/receptor complex, delaying internalisation and degradation of activated VEGFRs and thus potentiating downstream signalling [111]. Alterations in the balance of expression of VEGF isoforms may therefore affect biological responses.

Finally, increased binding of VEGF to 'decoy' receptors in early ARDS may also provide an explanation for 
the observations reported in the human lung. In support of this hypothesis, Perkins et al. [112] detected significant quantities of intrapulmonary soluble VEGFR1 protein in early ARDS compared to late ARDS or normal patients.

The observed increase in plasma VEGF levels may be partially explained by the release of VEGF from the intrapulmonary compartment, along a transepithelial gradient, following destruction of the ACM integrity. Moreover, ARDS represents only the pulmonary manifestation of widespread endothelial damage [34].

Activated macrophages [103] and neutrophils [113] also become a more important source of VEGF in ALI/ ARDS and may contribute to the increased levels of VEGF observed. VEGFR-1 has been identified on monocytes/ macrophages, the activation of which led to monocyte activation and chemotaxis. The authors hypothesised that apical AE2 cell VEGF secretion may play an additional role in the recruitment of immune cells into the alveolar space [114].

\section{Animal Studies}

One of the first studies attempting to understand the underlying mechanism of this increased vascular permeability demonstrated, using an adenoviral gene vector, that lung-targeted over-expression of human $\mathrm{VEGF}_{165}$ in mice resulted in pulmonary oedema and increased vascular permeability, suggesting a significant pathological role of VEGF in ARDS [115]. Furthermore, this effect could be attenuated by treatment with biological inhibitors of VEGF activity, both soluble VEGFR1 [115] and the antiVEGF antibody bevacizumab [116]. Similarly, pre-treatment of rats with adenovirus-encoding soluble VEGFR2 prevented ischemia-reperfusion-induced lung injury [117].

In homology with these findings, inhibition of VEGF activity with a soluble VEGF trap decoy receptor reduced vascular protein leak of hypoxic endothelin-B receptordeficient rats [118]. In these animals, vascular protein leak did not return to control levels, however, suggesting that VEGF activity is not the sole factor contributing to hypoxia-induced changes in vascular permeability.

Corroborative evidence that VEGF contributes to the initial exudative phase of ARDS was provided by Karmpaliotis et al. [119], who demonstrated increased immunostaining for VEGF in the lung, associated with the influx of mononuclear cells and neutrophils in the alveolar compartment, using an LPS-induced lung injury model. This finding was paralleled by an increase in VEGF mRNA expression, development of inflammation, capillary leakage and lung oedema [119].
Using an ovine smoke inhalation and pneumonia model of lung injury, Lange et al. [120] attempted to evaluate the time course of changes in VEGF expression. Linear increases in transvascular fluid flux and lung water content were observed following induction of lung injury. Transient increases in microvascular permeability were observed $12 \mathrm{~h}$ after lung injury, occurring concurrently with peak levels of total lung VEGF protein levels (measured by immunoblotting).

Increased VEGF and VEGFR2 expression in the lung has also been reported in an animal model of sea water immersion after open chest trauma-induced ALI [120122].

Moreover, in an in vivo mouse model of high tidal volume, mechanical ventilation [124], a ventilation strategy previously associated with increased lung injury [123], increased microvascular permeability, neutrophil influx, epithelial apoptosis and VEGF mRNA and protein production were observed, which were attenuated by knockdown of VEGF by short interfering RNAs.

The chronological expression of VEGF has also been studied in an LPS-induced model of lung injury [122]. In contrast to those studies previously discussed, VEGF protein expression in pulmonary tissue, as determined by ELISA and immunoblotting, was down-regulated in a time-dependent manner in response to injury. Furthermore, pulmonary levels of its angiogenic mediator, VEGFR2, and two important downstream signalling molecules (phosphorylated Akt and endothelial nitric oxide synthase) were also down-regulated in a similar manner. In contrast, plasma levels of VEGF and VEGFR1 increased following LPS administration (peaking at $6 \mathrm{~h}$ ). Blockade of VEGFR1 led to partial resolution of pulmonary VEGF levels and attenuated some features of ALI, suggesting that VEGF may play a pathological role through VEGFR1 in LPS-induced ALI.

In summary, numerous reports suggest a pathological role for VEGF in ALI/ARDS. Reports apparently conflict on whether VEGF expression is increased or decreased within the lung, and this may be explained in part due to the numerous models of lung injury used, in addition to different methodologies and end points.

\section{VEGF in the Fibroproliferative Phase of ALI/ARDS}

The fibroproliferative phase of ALI/ARDS is characterised by AE2 cell proliferation in an attempt to repair the denuded epithelium [125] and migration of fibroblasts into the interstitium and intra-alveolar space with 
deposition of collagen-rich extracellular matrix [125]. Evidence suggests that fibroproliferation is an early response to lung injury, occurring in parallel with the exudative phase [8].

\section{Human and Cellular Studies}

VEGF $_{165}$ induces the proliferation of AE2 cells in culture, an effect that can be inhibited by $\mathrm{VEGF}_{165} \mathrm{~b}$ [126], thus factors that alter VEGF gene splicing may affect the fibroproliferative response in ARDS. The effect of VEGF on AE2 proliferation is discussed further in the section: 'VEGF in Resolution/Repair from ARDS'.

\section{Animal Studies}

The role of VEGF in the development of fibrosis in ARDS has not specifically been addressed, although numerous studies of idiopathic pulmonary fibrosis exist, supporting a possible pro-fibrotic role. Using animal models of pulmonary fibrosis, VEGFR2 inhibition attenuated pulmonary collagen deposition and TGF- $\beta_{1}$ signalling [127], whilst anti-VEGF therapy in the form of sFlt-1 resulted in a reduction in lung collagen deposition with additional anti-inflammatory and anti-angiogenic effects [128]. In contrast, targeted myeloid cell-specific deletion of VEGF aggravated bleomycin-induced pulmonary fibrosis [125], whilst mice with EC-specific VEGF deletion developed de novo pulmonary fibrosis that preceded multi-organ failure from systemic vascular pathologies [126].

There are apparent conflicting findings as to the role of VEGF in animal models of pulmonary fibrosis. Furthermore, the underlying pathogenesis of fibrosis in ARDS may differ compared to other diseases/disease models and thus it is difficult to draw conclusions about ALI/ADRS from these studies. Research is required to explore this area in more detail $[129,130]$.

\section{VEGF in Resolution/Repair from ARDS}

Resolution of ARDS requires termination of the fibroproliferative response, a functioning ACM to facilitate clearance of pulmonary oedema and removal of inflammatory cells and MSCs [125].

\section{Human and Cellular Studies}

Observational human studies suggest a role for VEGF in the recovery from ARDS. It has been observed that in patients with ARDS, elevated plasma levels of VEGF become reduced in those who recover, whilst intrapulmonary VEGF levels that are reduced in early ARDS rise in recovery [103]. Furthermore, in human ARDS lung samples, VEGF levels were negatively correlated with apoptotic EC counts [131]. Differential temporal up-regulation of VEGFR1, VEGFR2 and NRP1 in human ARDS provides corroborative evidence of functional regulation of VEGF bioactivity via VEGFR2, consistent with a protective role of VEGF in recovery from lung injury [68].

The presence of $\mathrm{VEGF}_{165} \mathrm{~b}$ has also been demonstrated in healthy human lung tissue, with reduced levels of pulmonary expression reported in ARDS [126]. In vitro experiments have indicated that $\mathrm{VEGF}_{165} \mathrm{~b}$ inhibits the proliferative effect of recombinant $\mathrm{VEGF}_{165}$ protein on both human primary ECs and AE2 cells [126]. Taken together, these results also suggest a possible protective role for the $\mathrm{VEGF}_{\mathrm{xxx}} \mathrm{b}$ family in fibroproliferation/repair after lung injury.

Destruction of the vascular endothelium is characteristic of the hyperoxic model of lung injury and recovery requires proliferation of ECs. Using this model, AE2 cells were shown to express increased VEGF mRNA during recovery [132], further implicating VEGF in the regulation of ACM repair following injury.

\section{Animal Studies}

Over-expression of IL-13 in transgenic mice conferred survival benefit from hyperoxia-induced lung injury, associated with isoform-specific (120-and 188-amino acid isoforms) increases in broncho-alveolar lavage fluid VEGF [133].

Likewise, transgenic overexpression of $\mathrm{VEGF}_{165}$ conferred cytoprotection against hyperoxic lung injury, which in part was mediated through enhanced production of A1 [134].

It remains to be established, however, whether enhanced VEGF expression in the fibroproliferative/recovery phases of ARDS/ALI represents a marker of resolution or is actively participating in the repair process $[80$, $84,87,92,94,133,135]$.

\section{VEGF Has Both a Pathological and a Protective Role in the Lung in Health and Disease}

An elegant study by Mura et al. [91] attempts to draw together the role of VEGF in health and disease. In this study, conditional knockout of VEGF in mouse lung AE2 cells led to the development of emphysema in 28- to 32-week-old animals. Conditional targeting did, however, not significantly affect lung development from the embryonic to the young adult stage, suggesting that 

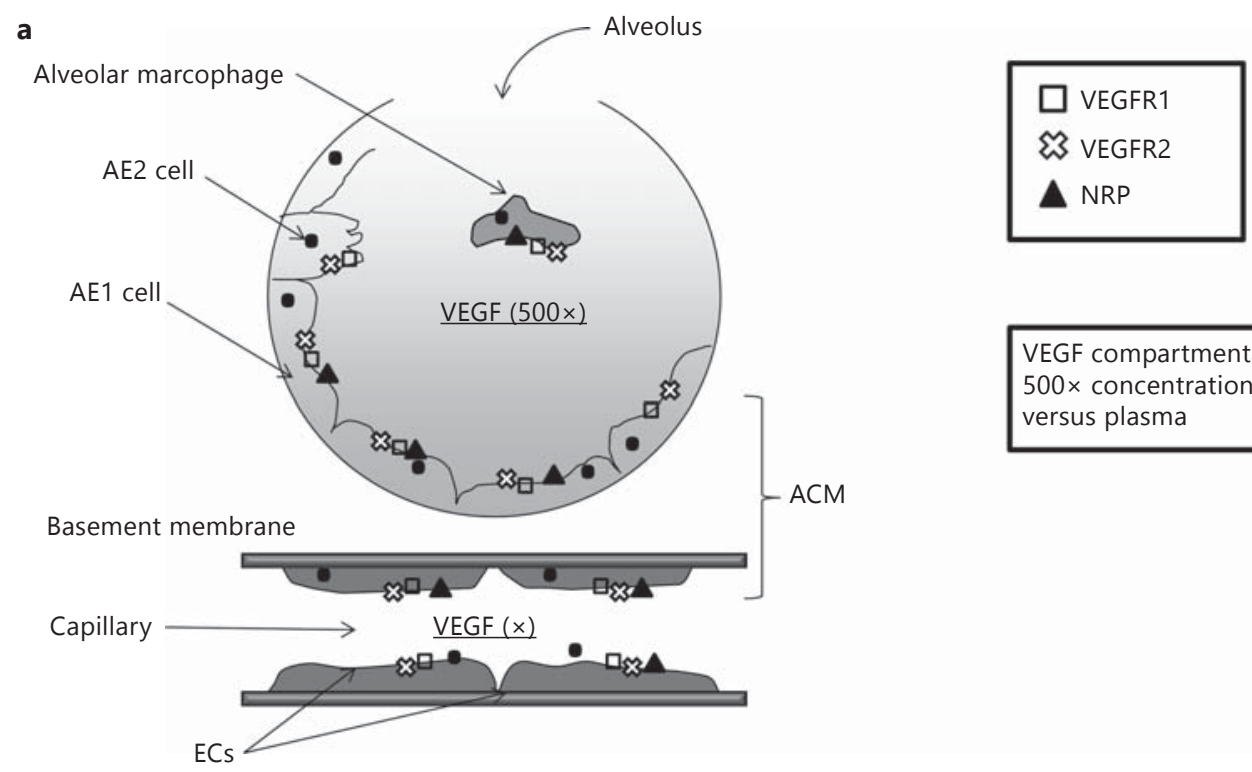

VEGF compartmentalisation $500 \times$ concentration in airspace versus plasma

b

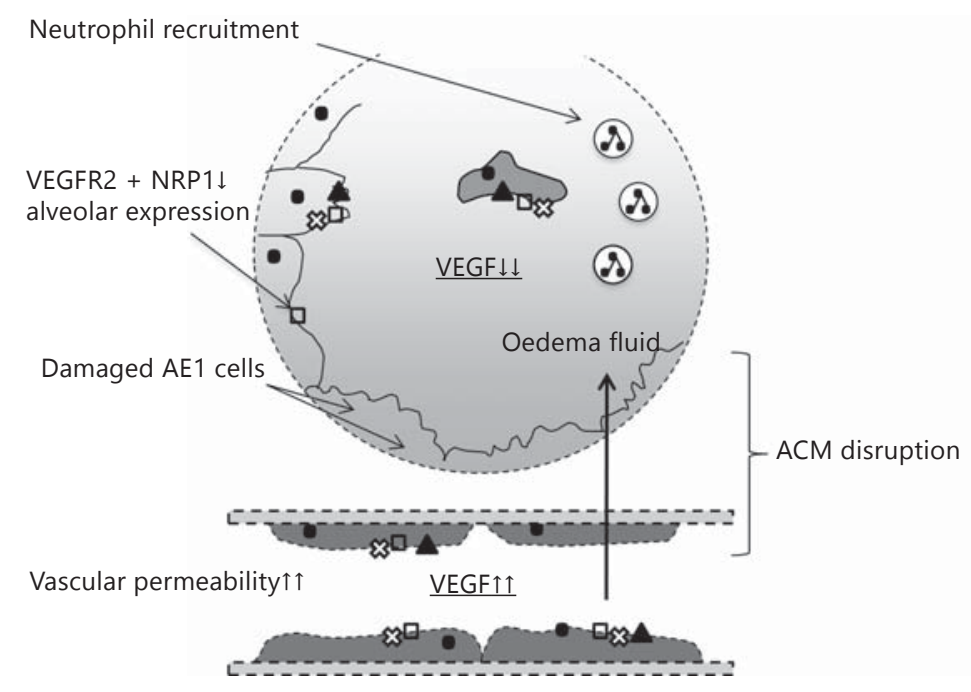

$\square$ VEGFR1

« VEGFR2

$\triangle \mathrm{NRP}$

Disruption of ACM integrity with reduction in

intrapulmonary VEGF levels

VEGF is critical in the maintenance of normal alveolar structures, especially in older individuals. In an in vivo model of extrapulmonary ARDS (intestinal ischemia-reperfusion) using young adult transgenic mice (7-10 weeks), features of attenuated lung injury were demonstrated compared to wild-type controls, in keeping with the known role of VEGF as a vascular permeability factor. Interestingly, increased caspase-3-positive AE2 cells were also detected following intestinal ischemia-reperfusion. Thus, results from targeted blockade of VEGF in AE2 cells point to a complex role for VEGF in ALI/ARDS as an important factor contributing to the acute inflammatory response and pulmonary oedema on the one hand, and as a protective factor for the alveolar epithelial barrier on the other.

\section{VEGF Therapy in ALI/ARDS}

This review has highlighted a potential pathological role for VEGF in the development of pulmonary oedema associated with ALI/ARDS. Anti-VEGF therapies in 


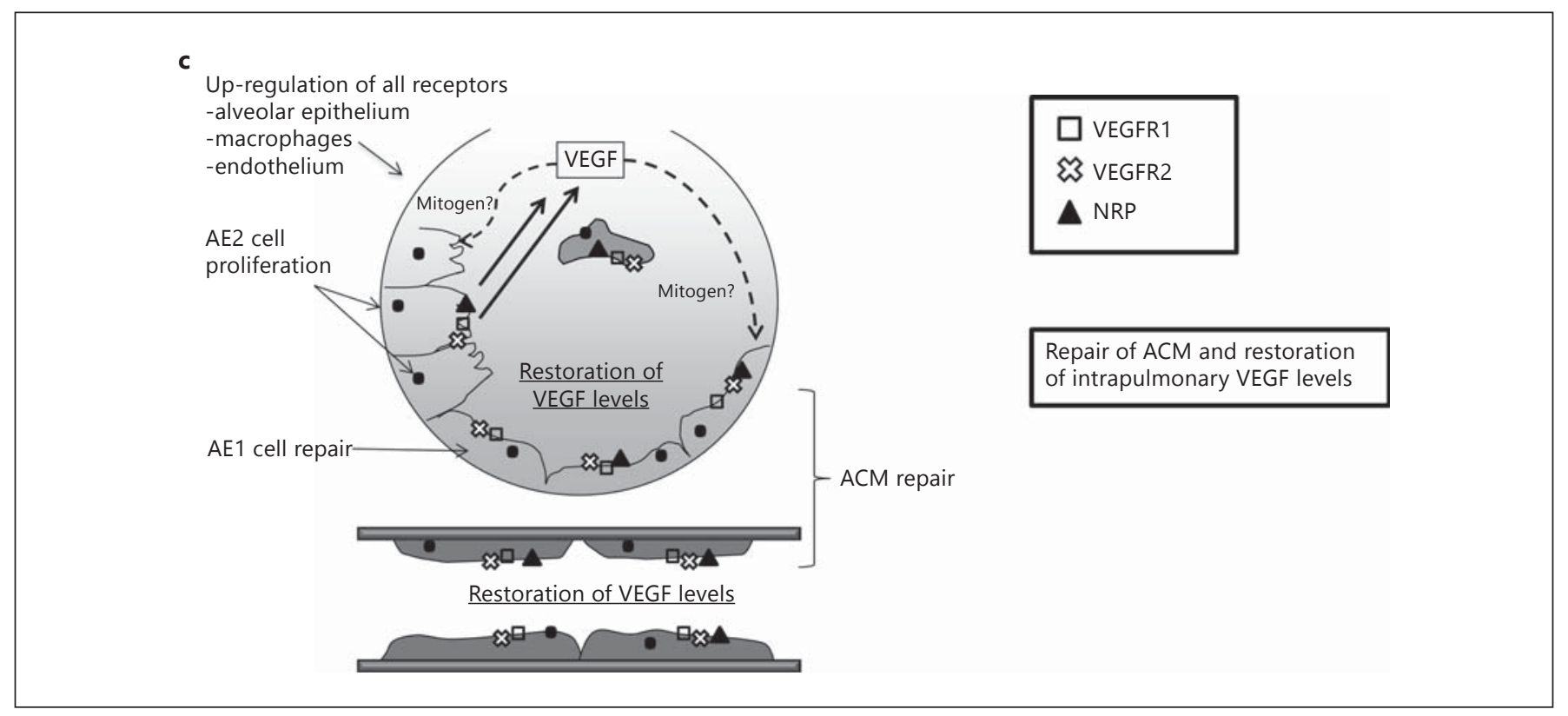

Fig. 2. Schematic diagram of the human alveolar unit in health (a), in early ARDS (1-2 days; b) and in late ARDS and recovery (c).

the form of monoclonal antibodies, e.g. bevacizumab (Avastin) and tyrosine kinase inhibitors, e.g. sunitinib (Sutent), have already been developed for the treatment of certain cancers [136-138] and age-related macular degeneration [139]. These therapies have a significant adverse effect profile following systemic administration, including hypertension, proteinuria, cardiac ischaemia, cerebral thrombosis and gastrointestinal perforation [140].

Clinical trials are required to establish the efficacy of drugs targeting VEGF/VEGFR in ARDS. Unfortunately, a planned phase 2 clinical trial studying the efficacy of bevacizumab in preventing ARDS (NCT01314066) has recently been withdrawn, prior to enrolment, due to inadequate funding.

Modulation of the fibroproliferative response provides an additional potential therapeutic target for ALI/ ARDS. It is possible to speculate that pro-angiogenic therapy may stimulate the repair of the ACM and alleviate the pulmonary oedema associated with ALI/ARDS.

In keeping with this theory, Compernolle et al. [87] demonstrated a beneficial effect of VEGF administration during the respiratory distress syndrome in neonatal mice that was mediated through VEGFR2. Additionally, Corne et al. [133] found that mice transfected with IL-13 during hyperoxia-induced lung injury had an increase in survival that was mediated in part by an increase in VEGF synthesis [133]. Over-expression of
VEGF in mice has, however, also been associated with increased mortality linked to pulmonary haemorrhage [95].

Trials of adenoviral [141] and plasmid [8] vectors expressing VEGF have failed in ischaemic heart disease due to side effects and lack of efficacy.

Our current understanding of the complex role VEGF may play in lung maintenance, injury and repair is incomplete. Studies presented in this review have implicated VEGF as both a pathological and protective factor in the exudative and fibroproliferative phases of ARDS, which occur concurrently. VEGF also plays an important physiological role in various other organ systems and has potential pleiotropic effects $[8,141]$. The greatest challenge in developing future modulatory VEGF therapy for ALI/ARDS would therefore be in its delivery in a controlled yet targeted manner.

\section{Conclusions}

Significant amounts of VEGF exist in the normal lung in the absence of significant mitogenesis, angiogenesis or vascular leakiness. There are apparent contradictory data on the role of VEGF in lung maintenance and in ALI/ ARDS that may be explained in part due to methodological differences in study design. It highlights the difficulty of drawing conclusions from studies that use different 
animal models of ALI and sample different biological compartments at different time points.

Furthermore, in both humans and animals, ALI/ARDS is a heterogeneous condition that has rapidly evolving phases, in which VEGF may play different or even opposing roles. Questions regarding the exact role of VEGF on the epithelial-endothelial barrier and the potential role for VEGF in the evolving stages of ARDS are being explored but remain unanswered.

To date, VEGF-A has been the most widely studied member of the human VEGF gene super-family. This review has highlighted the paucity of information regarding the role of other VEGF family members in ALI/ARDS. Whilst dissection of the underlying cellular and molecular processes is crucial, exploring the intricate interplay of the other family members in this complex syndrome is also paramount.
We have previously speculated that VEGF may function as a protective factor in the normal lung facilitating lung repair following injury through epithelial regeneration and yet become pathological, contributing to the development of pulmonary oedema across the underlying endothelium if the integrity of the ACM is breached [15]. Data to support this paradigm are accumulating [91] (fig. 2).

In the long term, a greater understanding of VEGF biology and the regulation of VEGF bioavailability in health and disease is required before treatments modulating VEGF may be used in ALI/ARDS.

\section{Financial Disclosure and Conflicts of Interest}

None to declare.

\section{References}

1 Katzenstein AL, Bloor CM, Leibow AA: Diffuse alveolar damage - the role of oxygen, shock, and related factors. A review. Am J Pathol 1976;85:209-228.

-2 Ashbaugh DG, Bigelow DB, Petty TL, Levine BE: Acute respiratory distress in adults. Lancet 1967;ii:319-323.

3 Matthay MA, Zimmerman GA: Acute lung injury and the acute respiratory distress syndrome: four decades of inquiry into pathogenesis and rational management. Am J Respir Cell Mol Biol 2005;33:319-327.

-4 Spragg RG, Bernard GR, Checkley W, Curtis JR, Gajic O, Guyatt G, Hall J, Israel E, Jain M, Needham DM, Randolph AG, Rubenfeld GD, Schoenfeld D, Thompson BT, Ware LB, Young D, Harabin AL: Beyond mortality: future clinical research in acute lung injury. Am J Respir Crit Care Med 2010;181:1121-1127.

5 Li G, Malinchoc M, Cartin-Ceba R, Venkata CV, Kor DJ, Peters SG, Hubmayr RD, Gajic O: Eight-year trend of acute respiratory distress syndrome: a population-based study in Olmsted County, Minnesota. Am J Respir Crit Care Med 2011;183:59-66.

-6 Toy P, Gajic O, Bacchetti P, Looney MR, Gropper MA, Hubmayr R, Lowell CA, Norris PJ, Murphy EL, Weiskopf RB, Wilson G, Koenigsberg M, Lee D, Schuller R, Wu P, Grimes B, Gandhi MJ, Winters JL, Mair D, Hirschler N, Sanchez Rosen R, Matthay MA: Transfusion-related acute lung injury: incidence and risk factors. Blood 2012;119:1757-1767.

7 Luyt CE, Combes A, Becquemin MH, Beigelman-Aubry C, Hatem S, Brun AL, Zraik N, Carrat F, Grenier PA, Richard JC, Mercat A, Brochard L, Brun-Buisson C, Chastre J: Longterm outcomes of pandemic 2009 influenza
A(H1N1)-associated severe ARDS. Chest 2012;142:583-592.

-8 Sarkar N, Rück A, Källner G, Y-Hassan S, Blomberg P, Islam KB, van der Linden J, Lindblom D, Nygren AT, Lind B, Brodin LA, Drvota V, Sylvén C: Effects of intramyocardial injection of phVEGF-A165 as sole therapy in patients with refractory coronary artery disease - 12-month follow-up: angiogenic gene therapy. J Intern Med 2001;250:373-381.

-9 Armstrong L, Thickett DR, Mansell JP, Ionescu M, Hoyle E, Billinghurst RC, Poole AR, Millar AB: Changes in collagen turnover in early acute respiratory distress syndrome. Am J Respir Crit Care Med 1999;160:1910-1915.

10 Plouet J, Schilling J, Gospodarowicz D: Isolation and characterization of a newly identified endothelial cell mitogen produced by AtT-20 cells. EMBO J 1989;8:3801-3806.

11 Carmeliet P, Ferreira V, Breier G, Pollefeyt S, Kieckens L, Gertsenstein M, Fahrig M, Vandenhoeck A, Harpal K, Eberhardt C, Declercq C, Pawling J, Moons L, Collen D, Risau W, Nagy A: Abnormal blood vessel development and lethality in embryos lacking a single VEGF allele. Nature 1996;380:435-439.

12 Ferrara N, Carver-Moore K, Chen H, Dowd M, Lu L, O'Shea KS, Powell-Braxton L, Hillan KJ, Moore MW: Heterozygous embryonic lethality induced by targeted inactivation of the VEGF gene. Nature 1996;380:439-442.

13 Monacci WT, Merrill MJ, Oldfield EH: Expression of vascular permeability factor/vascular endothelial growth factor in normal rat tissues. Am J Physiol 1993;264:C995-C1002.

14 Berse B, Brown LF, Van de Water L, Dvorak HF, Senger DR: Vascular permeability factor (vascular endothelial growth factor) gene is expressed differentially in normal tissues, macrophages, and tumors. Mol Biol Cell 1992;3:211-220.

15 Medford AR, Millar AB: Vascular endothelial growth factor (VEGF) in acute lung injury (ALI) and acute respiratory distress syndrome (ARDS): paradox or paradigm? Tho$\operatorname{rax} 2006 ; 61: 621-626$.

16 Ferrara N, Gerber HP, LeCouter J: The biology of VEGF and its receptors. Nat Med 2003; 9:669-676

17 Senger DR, Galli SJ, Dvorak AM, Perruzzi CA, Harvey VS, Dvorak HF: Tumor cells secrete a vascular permeability factor that promotes accumulation of ascites fluid. Science 1983;219:983-985.

18 Ferrara N, Henzel WJ: Pituitary follicular cells secrete a novel heparin-binding growth factor specific for vascular endothelial cells. Biochem Biophys Res Commun 1989;161:851858 .

19 Tischer E, Mitchell R, Hartman T, Silva M, Gospodarowicz D, Fiddes JC, Abraham JA: The human gene for vascular endothelial growth factor. Multiple protein forms are encoded through alternative exon splicing. J Biol Chem 1991;266:11947-11954.

20 Park JE, Keller GA, Ferrara N: The vascular endothelial growth factor (VEGF) isoforms: differential deposition into the subepithelial extracellular matrix and bioactivity of extracellular matrix-bound VEGF. Mol Biol Cell 1993;4:1317-1326.

21 Houck KA, Leung DW, Rowland AM, Winer J, Ferrara N: Dual regulation of vascular endothelial growth factor bioavailability by genetic and proteolytic mechanisms. J Biol Chem 1992;267:26031-26037. 
22 Bates DO, Cui TG, Doughty JM, Winkler M, Sugiono M, Shields JD, Peat D, Gillatt D, Harper SJ: VEGF165b, an inhibitory splice variant of vascular endothelial growth factor, is down-regulated in renal cell carcinoma. Cancer Res 2002;62:4123-4131.

23 Keyt BA, Nguyen HV, Berleau LT, Duarte $\mathrm{CM}$, Park J, Chen H, Ferrara N: Identification of vascular endothelial growth factor determinants for binding KDR and FLT-1 receptors. Generation of receptor-selective VEGF variants by site-directed mutagenesis. J Biol Chem 1996;271:5638-5646.

24 Woolard J, Wang WY, Bevan HS, Qiu Y, Morbidelli L, Pritchard-Jones RO, Cui TG, Sugiono M, Waine E, Perrin R, Foster R, Digby-Bell J, Shields JD, Whittles CE, Mushens RE, Gillatt DA, Ziche M, Harper SJ, Bates DO: VEGF165b, an inhibitory vascular endothelial growth factor splice variant: mechanism of action, in vivo effect on angiogenesis and endogenous protein expression. Cancer Res 2004;64:7822-7835.

25 Olofsson B, Korpelainen E, Pepper MS, Mandriota SJ, Aase K, Kumar V, Gunji Y, Jeltsch MM, Shibuya M, Alitalo K, Eriksson U: Vascular endothelial growth factor b (VEGF-B) binds to VEGF receptor-1 and regulates plasminogen activator activity in endothelial cells. Proc Natl Acad Sci USA 1998;95:11709-11714.

-26 Joukov V, Pajusola K, Kaipainen A, Chilov D, Lahtinen I, Kukk E, Saksela O, Kalkkinen $\mathrm{N}$, Alitalo K: A novel vascular endothelial growth factor, VEGF-C, is a ligand for the Flt4 (VEGFR-3) and KDR (VEGFR-2) receptor tyrosine kinases. EMBO J 1996;15:1751.

-27 Olofsson B, Pajusola K, Kaipainen A, von Euler G, Joukov V, Saksela O, Orpana A, Pettersson RF, Alitalo K, Eriksson U: Vascular endothelial growth factor B, a novel growth factor for endothelial cells. Proc Natl Acad Sci USA 1996;93:2576-2581.

28 Yamazaki Y, Morita T: Molecular and functional diversity of vascular endothelial growth factors. Mol Divers 2006;10:515-527.

29 Makinen T, Olofsson B, Karpanen T, Hell- 39 man U, Soker S, Klagsbrun M, Eriksson U, Alitalo K: Differential binding of vascular endothelial growth factor B splice and proteolytic isoforms to neuropilin-1. J Biol Chem 1999;274:21217-21222.

30 Bellomo D, Headrick JP, Silins GU, Paterson CA, Thomas PS, Gartside M, Mould A, Cahill MM, Tonks ID, Grimmond SM, Townson S, Wells C, Little M, Cummings MC, Hayward NK, Kay GF: Mice lacking the vascular endothelial growth factor-B gene (Vegfb) have smaller hearts, dysfunctional coronary vasculature, and impaired recovery from cardiac ischemia. Circ Res 2000;86:E29-E35.

- 31 Zhang F, Tang Z, Hou X, Lennartsson J, Li Y, Koch AW, Scotney P, Lee C, Arjunan P, Dong L, Kumar A, Rissanen TT, Wang B, Nagai N, Fons P, Fariss R, Zhang Y, Wawrousek E, Tansey G, Raber J, Fong GH, Ding H, Greenberg DA, Becker KG, Herbert JM, Nash A, Yla-Herttuala S, Cao Y, Watts RJ, Li X: VEGF-
$\mathrm{B}$ is dispensable for blood vessel growth but critical for their survival, and VEGF-B targeting inhibits pathological angiogenesis. Proc Natl Acad Sci USA 2009;106:6152-6157.

- 32 Wanstall JC, Gambino A, Jeffery TK, Cahill MM, Bellomo D, Hayward NK, Kay GF: Vascular endothelial growth factor-B-deficient mice show impaired development of hypoxic pulmonary hypertension. Cardiovasc Res 2002;55:361-368.

33 Louzier V, Raffestin B, Leroux A, Branellec D, Caillaud JM, Levame M, Eddahibi S, Adnot S: Role of VEGF-B in the lung during development of chronic hypoxic pulmonary hypertension. Am J Physiol Lung Cell Mol Physiol 2003;284:L926-L937.

34 Mura M, dos Santos CC, Stewart D, Liu M: Vascular endothelial growth factor and related molecules in acute lung injury. J Appl Physiol 2004;97:1605-1617.

- 35 Wirzenius M, Tammela T, Uutela M, He Y, Odorisio T, Zambruno G, Nagy JA, Dvorak HF, Yla-Herttuala S, Shibuya M, Alitalo K: Distinct vascular endothelial growth factor signals for lymphatic vessel enlargement and sprouting. J Exp Med 2007;204:1431-1440.

- 36 Achen MG, Jeltsch M, Kukk E, Makinen T, Vitali A, Wilks AF, Alitalo K, Stacker SA: Vascular endothelial growth factor D (VEGF-D) is a ligand for the tyrosine kinases VEGF receptor 2 (Flk1) and VEGF receptor 3 (Flt4). Proc Natl Acad Sci USA 1998;95:548-553.

-37 Saaristo A, Veikkola T, Enholm B, Hytonen M, Arola J, Pajusola K, Turunen P, Jeltsch M, Karkkainen MJ, Kerjaschki D, Bueler H, YlaHerttuala S, Alitalo K: Adenoviral VEGF-C overexpression induces blood vessel enlargement, tortuosity, and leakiness but no sprouting angiogenesis in the skin or mucous membranes. FASEB J 2002;16:1041-1049.

38 Stacker SA, Caesar C, Baldwin ME, Thornton GE, Williams RA, Prevo R, Jackson DG, Nishikawa S, Kubo H, Achen MG: VEGF-D promotes the metastatic spread of tumor cells via the lymphatics. Nat Med 2001;7:186-191.

Ogawa S, Oku A, Sawano A, Yamaguchi S, Yazaki Y, Shibuya M: A novel type of vascular endothelial growth factor, VEGF-E (NZ-7 VEGF), preferentially utilizes KDR/Flk-1 receptor and carries a potent mitotic activity without heparin-binding domain. J Biol Chem 1998;273:31273-31282.

40 Persico MG, Vincenti V, DiPalma T: Structure, expression and receptor-binding properties of placenta growth factor (PlGF). Curr Top Microbiol Immunol 1999;237:31-40.

41 Park JE, Chen HH, Winer J, Houck KA, Ferrara N: Placenta growth factor. Potentiation of vascular endothelial growth factor bioactivity, in vitro and in vivo, and high affinity binding to Flt-1 but not to Flk-1/KDR. J Biol Chem 1994;269:25646-25654.

42 Autiero M, Waltenberger J, Communi D, Kranz A, Moons L, Lambrechts D, Kroll J, Plaisance S, De Mol M, Bono F, Kliche S, Fellbrich G, Ballmer-Hofer K, Maglione D, MayrBeyrle U, Dewerchin M, Dombrowski S, Sta- nimirovic D, Van Hummelen P, Dehio C, Hicklin DJ, Persico G, Herbert JM, Shibuya M, Collen D, Conway EM, Carmeliet P: Role of PlGF in the intra- and intermolecular cross talk between the VEGF receptors Flt1 and Flk1. Nat Med 2003;9:936-943.

43 Tsao PN, Su YN, Li H, Huang PH, Chien CT, Lai YL, Lee CN, Chen CA, Cheng WF, Wei SC, Yu CJ, Hsieh FJ, Hsu SM: Overexpression of placenta growth factor contributes to the pathogenesis of pulmonary emphysema. Am J Respir Crit Care Med 2004;169:505-511.

44 Sands M, Howell K, Costello CM, McLoughlin P: Placenta growth factor and vascular endothelial growth factor B expression in the hypoxic lung. Respir Res 2011;12:17.

45 Kaipainen A, Korhonen J, Mustonen T, van Hinsbergh VW, Fang GH, Dumont D, Breitman M, Alitalo K: Expression of the fms-like tyrosine kinase 4 gene becomes restricted to lymphatic endothelium during development. Proc Natl Acad Sci USA 1995;92:3566-3570.

46 Carmeliet P, Moons L, Luttun A, Vincenti V, Compernolle V, De Mol M, Wu Y, Bono F, Devy L, Beck H, Scholz D, Acker T, DiPalma T, Dewerchin M, Noel A, Stalmans I, Barra A, Blacher S, Vandendriessche T, Ponten A, Eriksson U, Plate KH, Foidart JM, Schaper W, Charnock-Jones DS, Hicklin DJ, Herbert JM, Collen D, Persico MG: Synergism between vascular endothelial growth factor and placental growth factor contributes to angiogenesis and plasma extravasation in pathological conditions. Nat Med 2001;7:575-583.

47 Matsumoto T, Claesson-Welsh L: Vegf receptor signal transduction. Sci STKE 2001;2001:re21.

48 Millauer B, Wizigmann-Voos S, Schnurch H, Martinez R, Moller NP, Risau W, Ullrich A: High affinity VEGF binding and developmental expression suggest Flk-1 as a major regulator of vasculogenesis and angiogenesis. Cell 1993;72:835-846.

49 Norden AD, Drappatz J, Wen PY: Antiangiogenic therapies for high-grade glioma. Nat Rev Neurol 2009;5:610-620.

50 Shalaby F, Rossant J, Yamaguchi TP, Gertsenstein $\mathrm{M}, \mathrm{Wu} \mathrm{XF}, \mathrm{Breitman} \mathrm{ML}$, Schuh AC: Failure of blood-island formation and vasculogenesis in Flk-1-deficient mice. Nature 1995;376:62-66.

-51 Fehrenbach H, Haase M, Kasper M, Koslowski R, Schuh D, Muller M: Alterations in the immunohistochemical distribution patterns of vascular endothelial growth factor receptors Flk1 and Flt1 in bleomycin-induced rat lung fibrosis. Virchows Arch 1999;435:20-31.

52 de Vries C, Escobedo JA, Ueno H, Houck K, Ferrara N, Williams LT: The fms-like tyrosine kinase, a receptor for vascular endothelial growth factor. Science 1992;255:989-991.

53 Shinkai A, Ito M, Anazawa H, Yamaguchi S, Shitara K, Shibuya M: Mapping of the sites involved in ligand association and dissociation at the extracellular domain of the kinase insert domain-containing receptor for vascular endothelial growth factor. J Biol Chem 1998;273:31283-31288. 
-54 Takahashi T, Shirasawa T, Miyake K, Yahagi Y, Maruyama N, Kasahara N, Kawamura T, Matsumura O, Mitarai T, Sakai O: Protein tyrosine kinases expressed in glomeruli and cultured glomerular cells: Flt-1 and VEGF expression in renal mesangial cells. Biochem Biophys Res Commun 1995;209:218-226.

55 Sawano A, Iwai S, Sakurai Y, Ito M, Shitara K, Nakahata T, Shibuya M: Flt-1, vascular endothelial growth factor receptor 1 , is a novel cell surface marker for the lineage of monocytemacrophages in humans. Blood 2001;97:785791.

56 Maniscalco WM, Watkins RH, D’Angio CT, Ryan RM: Hyperoxic injury decreases alveolar epithelial cell expression of vascular endothelial growth factor (VEGF) in neonatal rabbit lung. Am J Respir Cell Mol Biol 1997;16: 557-567.

57 Waltenberger J, Claesson-Welsh L, Siegbahn A, Shibuya M, Heldin CH: Different signal transduction properties of KDR and Flt1, two receptors for vascular endothelial growth factor. J Biol Chem 1994;269:26988-26995.

58 Kendall RL, Thomas KA: Inhibition of vascular endothelial cell growth factor activity by an endogenously encoded soluble receptor. Proc Natl Acad Sci USA 1993;90:10705-10709.

-59 Fuh G, Li B, Crowley C, Cunningham B, Wells JA: Requirements for binding and signaling of the kinase domain receptor for vascular endothelial growth factor. J Biol Chem 1998;273:11197-11204.

-60 Koch S, Tugues S, Li X, Gualandi L, ClaessonWelsh L: Signal transduction by vascular endothelial growth factor receptors. Biochem J 2011;437:169-183.

-61 Zhang Z, Neiva KG, Lingen MW, Ellis LM, Nor JE: VEGF-dependent tumor angiogenesis requires inverse and reciprocal regulation of VEGFR1 and VEGFR2. Cell Death Differ 2010;17:499-512.

-62 Kanno S, Oda N, Abe M, Terai Y, Ito M, Shitara K, Tabayashi K, Shibuya M, Sato Y: Roles of two VEGF receptors, Flt-1 and KDR, in the signal transduction of VEGF effects in human vascular endothelial cells. Oncogene 2000;19: 2138-2146.

63 Kitsukawa T, Shimizu M, Sanbo M, Hirata T, Taniguchi M, Bekku Y, Yagi T, Fujisawa H: Neuropilin-semaphorin III/D-mediated chemorepulsive signals play a crucial role in peripheral nerve projection in mice. Neuron 1997;19:995-1005.

-64 Kolodkin AL, Levengood DV, Rowe EG, Tai YT, Giger RJ, Ginty DD: Neuropilin is a semaphorin III receptor. Cell 1997;90:753-762.

65 Chen H, Chedotal A, He Z, Goodman CS, Tessier-Lavigne M: Neuropilin-2, a novel member of the neuropilin family, is a high affinity receptor for the semaphorins Sema E and Sema IV but not Sema III. Neuron 1997; 19:547-559.

- 66 Soker S, Takashima S, Miao HQ, Neufeld G, Klagsbrun M: Neuropilin-1 is expressed by endothelial and tumor cells as an isoformspecific receptor for vascular endothelial growth factor. Cell 1998;92:735-745.
67 Parker MW, Xu P, Li X, Vander Kooi CW: Structural basis for the selective vascular endothelial growth factor-A (VEGF-A) binding to neuropilin-1. J Biol Chem 2012;287:1108211089.

68 Medford AR, Ibrahim NB, Millar AB: Vascular endothelial growth factor receptor and coreceptor expression in human acute respiratory distress syndrome. J Crit Care 2009;24: 236-242.

69 Soker S, Fidder H, Neufeld G, Klagsbrun M: Characterization of novel vascular endothelial growth factor (VEGF) receptors on tumor cells that bind VEGF165 via its exon 7-encoded domain. J Biol Chem 1996;271:5761-5767.

-70 Brusselmans K, Bono F, Collen D, Herbert JM, Carmeliet P, Dewerchin M: A novel role for vascular endothelial growth factor as an autocrine survival factor for embryonic stem cells during hypoxia. J Biol Chem 2005;280: 3493-3499.

71 Oosthuyse B, Moons L, Storkebaum E, Beck $\mathrm{H}$, Nuyens D, Brusselmans K, Van Dorpe J, Hellings P, Gorselink M, Heymans S, Theilmeier G, Dewerchin M, Laudenbach V, Vermylen P, Raat H, Acker T, Vleminckx V, Van Den Bosch L, Cashman N, Fujisawa H, Drost MR, Sciot R, Bruyninckx F, Hicklin DJ, Ince C, Gressens P, Lupu F, Plate KH, Robberecht W, Herbert JM, Collen D, Carmeliet P: Deletion of the hypoxia-response element in the vascular endothelial growth factor promoter causes motor neuron degeneration. Nat Genet 2001;28:131-138.

72 Pidgeon GP, Barr MP, Cathcart MC, Gray S, O'Byrne KJ: Neuropilin-1 expression in adenocarcinoma and squamous cell carcinoma of the lung is differentially regulated by hypoxia. J Clin Oncol 24(suppl 18s):679s, abstr 17152.

73 Neufeld G, Cohen T, Gengrinovitch S, Poltorak Z: Vascular endothelial growth factor (VEGF) and its receptors. FASEB J 1999;13: 9-22.

74 Grunewald FS, Prota AE, Giese A, BallmerHofer K: Structure-function analysis of VEGF receptor activation and the role of coreceptors in angiogenic signaling. Biochim Biophys Acta 2010;1804:567-580.

75 Le A, Zielinski R, He C, Crow MT, Biswal S, Tuder RM, Becker PM: Pulmonary epithelial neuropilin-1 deletion enhances development of cigarette smoke-induced emphysema. Am J Respir Crit Care Med 2009;180:396-406.

76 Kaner RJ, Crystal RG: Compartmentalization of vascular endothelial growth factor to the epithelial surface of the human lung. Mol Med 2001;7:240-246.

77 Dvorak HF, Brown LF, Detmar M, Dvorak AM: Vascular permeability factor/vascular endothelial growth factor, microvascular hyperpermeability, and angiogenesis. Am J Pathol 1995;146:1029-1039.

78 Yao JS, Shen F, Young WL, Yang GY: Comparison of doxycycline and minocycline in the inhibition of VEGF-induced smooth muscle cell migration. Neurochem Int 2007;50:524530 .
79 Wu WK, Llewellyn OP, Bates DO, Nicholson LB, Dick AD: IL-10 regulation of macrophage VEGF production is dependent on macrophage polarisation and hypoxia. Immunobiology 2010;215:796-803.

80 Mura M, Han B, Andrade CF, Seth R, Hwang D, Waddell TK, Keshavjee S, Liu M: The early responses of VEGF and its receptors during acute lung injury: implication of VEGF in alveolar epithelial cell survival. Crit Care 2006; 10:R130.

81 Roberts JR, Perkins GD, Fujisawa T, Pettigrew KA, Gao F, Ahmed A, Thickett DR: Vascular endothelial growth factor promotes physical wound repair and is anti-apoptotic in primary distal lung epithelial and A549 cells. Crit Care Med 2007;35:2164-2170.

82 Gerber HP, McMurtrey A, Kowalski J, Yan M, Keyt BA, Dixit V, Ferrara N: Vascular endothelial growth factor regulates endothelial cell survival through the phosphatidylinositol $3^{\prime}$-kinase/Akt signal transduction pathway. Requirement for Flk-1/KDR activation. J Biol Chem 1998;273:30336-30343.

83 Shifren JL, Doldi N, Ferrara N, Mesiano S, Jaffe RB: In the human fetus, vascular endothelial growth factor is expressed in epithelial cells and myocytes, but not vascular endothelium: implications for mode of action. J Clin Endocrinol Metab 1994;79:316-322.

-84 Kuhn H, Kruger S, Hammerschmidt S, Wirtz $\mathrm{H}$ : High concentrations of vascular endothelial growth factor reduce stretch-induced apoptosis of alveolar type II cells. Respirology 2010;15:343-348.

85 Leung DW, Cachianes G, Kuang WJ, Goeddel DV, Ferrara N: Vascular endothelial growth factor is a secreted angiogenic mitogen. Science 1989;246:1306-1309.

86 Brown KR, England KM, Goss KL, Snyder JM, Acarregui MJ: VEGF induces airway epithelial cell proliferation in human fetal lung in vitro. Am J Physiol Lung Cell Mol Physiol 2001;281:L1001-L1010.

87 Compernolle V, Brusselmans K, Acker T, Hoet P, Tjwa M, Beck H, Plaisance S, Dor Y, Keshet E, Lupu F, Nemery B, Dewerchin M, Van Veldhoven P, Plate K, Moons L, Collen D, Carmeliet P: Loss of HIF-2alpha and inhibition of VEGF impair fetal lung maturation, whereas treatment with VEGF prevents fatal respiratory distress in premature mice. Nat Med 2002;8:702-710.

88 Gerber HP, Dixit V, Ferrara N: Vascular endothelial growth factor induces expression of the antiapoptotic proteins $\mathrm{Bcl}-2$ and $\mathrm{Al}$ in vascular endothelial cells. J Biol Chem 1998; 273:13313-13316.

89 Alavi A, Hood JD, Frausto R, Stupack DG, Cheresh DA: Role of Raf in vascular protection from distinct apoptotic stimuli. Science 2003;301:94-96.

-90 Tang K, Rossiter HB, Wagner PD, Breen EC: Lung-targeted VEGF inactivation leads to an emphysema phenotype in mice. J Appl Physiol 2004;97:1559-1566, discussion 1549. 
91 Mura M, Binnie M, Han B, Li C, Andrade CF, Shiozaki A, Zhang Y, Ferrara N, Hwang D, Waddell TK, Keshavjee S, Liu M: Functions of type II pneumocyte-derived vascular endothelial growth factor in alveolar structure, acute inflammation, and vascular permeability. Am J Pathol 2010;176:17251734.

92 Kasahara Y, Tuder RM, Taraseviciene-Stewart L, Le Cras TD, Abman S, Hirth PK, Waltenberger J, Voelkel NF: Inhibition of VEGF receptors causes lung cell apoptosis and emphysema. J Clin Invest 2000;106: 1311-1319.

-93 Tuder RM, Kasahara Y, Voelkel NF: Inhibition of vascular endothelial growth factor receptors causes emphysema in rats. Chest 2000;117:281S.

\$4 Guan XJ, Song L, Han FF, Cui ZL, Chen X, Guo XJ, Xu WG: Mesenchymal stem cells protect cigarette smoke-damaged lung and pulmonary function partly via VEGF-VEGF receptors. J Cell Biochem 2013;114:323335.

$\$ 95$ Le Cras TD, Spitzmiller RE, Albertine KH, Greenberg JM, Whitsett JA, Akeson AL: VEGF causes pulmonary hemorrhage, hemosiderosis, and air space enlargement in neonatal mice. Am J Physiol Lung Cell Mol Physiol 2004;287:L134-L142.

$\$ 96$ Bhandari V, Choo-Wing R, Chapoval SP, Lee CG, Tang C, Kim YK, Ma B, Baluk P, Lin MI, McDonald DM, Homer RJ, Sessa WC, Elias JA: Essential role of nitric oxide in VEGF-induced, asthma-like angiogenic, inflammatory, mucus, and physiologic responses in the lung. Proc Natl Acad Sci USA 2006;103:11021-11026.

-97 Krebs R, Tikkanen JM, Ropponen JO, Jeltsch M, Jokinen JJ, Yla-Herttuala S, Nykanen AI, Lemstrom KB: Critical role of VEGF-C/ VEGFR-3 signaling in innate and adaptive immune responses in experimental obliterative bronchiolitis. Am J Pathol 2012;181: 1607-1620.

98 Medford AR, Godinho SI, Keen LJ, Bidwell JL, Millar AB: Relationship between vascular endothelial growth factor +936 genotype and plasma/epithelial lining fluid vascular endothelial growth factor protein levels in patients with and at risk for ARDS. Chest 2009;136:457-464.

99 Medford AR, Keen LJ, Bidwell JL, Millar AB: Vascular endothelial growth factor gene polymorphism and acute respiratory distress syndrome. Thorax 2005;60:244-248.

100 Yang S, Cao S, Li J, Chang J: Association between vascular endothelial growth factor + 936 genotype and acute respiratory distress syndrome in a Chinese population. Genet Test Mol Biomarkers 2011;15:737-740.

101 Kim JY, Hildebrandt MA, Pu X, Ye Y, Correa AM, Vaporciyan AA, Wu X, Roth JA: Variations in the vascular endothelial growth factor pathway predict pulmonary complications. Ann Thorac Surg 2012;94: 1079-1085.
102 Simpson A, Custovic A, Tepper R, Graves P, Stern DA, Jones M, Hankinson J, Curtin JA, $\mathrm{Wu}$ J, Blekic M, Bukvic BK, Aberle N, Marinho S, Belgrave D, Morgan WJ, Martinez FD: Genetic variation in vascular endothelial growth factor-A and lung function. Am J Respir Crit Care Med 2012;185:11971204.

103 Thickett DR, Armstrong L, Millar AB: A role for vascular endothelial growth factor in acute and resolving lung injury. Am J Respir Crit Care Med 2002;166:1332-1337.

104 Maitre B, Boussat S, Jean D, Gouge M, Brochard L, Housset B, Adnot S, Delclaux C: Vascular endothelial growth factor synthesis in the acute phase of experimental and clinical lung injury. Eur Respir J 2001;18:100106.

105 Azamfirei L, Gurzu S, Solomon R, Copotoiu R, Copotoiu S, Jung I, Tilinca M, Branzaniuc K, Corneci D, Szederjesi J, Kovacs J: Vascular endothelial growth factor: a possible mediator of endothelial activation in acute respiratory distress syndrome. Minerva Anestesiol 2010;76:609-616.

106 Bardales RH, Xie SS, Schaefer RF, Hsu SM: Apoptosis is a major pathway responsible for the resolution of type II pneumocytes in acute lung injury. Am J Pathol 1996;149: 845-852.

107 Martin TR, Nakamura M, Matute-Bello G: The role of apoptosis in acute lung injury. Crit Care Med 2003;31:S184-S188.

108 Tuder RM, Flook BE, Voelkel NF: Increased gene expression for VEGF and the VEGF receptors KDR/Flk and Flt in lungs exposed to acute or to chronic hypoxia. Modulation of gene expression by nitric oxide. J Clin Invest 1995;95:1798-1807.

109 Koehne P, Willam C, Strauss E, Schindler R, Eckardt KU, Buhrer C: Lack of hypoxic stimulation of VEGF secretion from neutrophils and platelets. Am J Physiol Heart Circ Physiol 2000;279:H817-H824.

110 Medford AR, Douglas SK, Godinho SI, Uppington KM, Armstrong L, Gillespie KM, van Zyl B, Tetley TD, Ibrahim NB, Millar $A B$ : Vascular endothelial growth factor (VEGF) isoform expression and activity in human and murine lung injury. Respir Res 2009;10:27.

-111 Jakobsson L, Kreuger J, Holmborn K, Lundin L, Eriksson I, Kjellen L, Claesson-Welsh L: Heparan sulfate in trans potentiates VEGFR-mediated angiogenesis. Dev Cell 2006;10:625-634.

112 Perkins GD, Roberts J, McAuley DF, Armstrong L, Millar A, Gao F, Thickett DR: Regulation of vascular endothelial growth factor bioactivity in patients with acute lung injury. Thorax 2005;60:153-158.

113 Gaudry M, Bregerie O, Andrieu V, El Benna J, Pocidalo MA, Hakim J: Intracellular pool of vascular endothelial growth factor in human neutrophils. Blood 1997;90:4153-4161.

114 Clauss M, Weich H, Breier G, Knies U, Rockl W, Waltenberger J, Risau W: The vascular endothelial growth factor receptor Flt-1 mediates biological activities. Implications for a functional role of placenta growth factor in monocyte activation and chemotaxis. J Biol Chem 1996;271:17629-17634.

115 Kaner RJ, Ladetto JV, Singh R, Fukuda N, Matthay MA, Crystal RG: Lung overexpression of the vascular endothelial growth factor gene induces pulmonary edema. Am J Respir Cell Mol Biol 2000;22:657-664.

116 Watanabe M, Boyer JL, Crystal RG: Genetic delivery of bevacizumab to suppress vascular endothelial growth factor-induced highpermeability pulmonary edema. Hum Gene Ther 2009;20:598-610.

117 Godzich M, Hodnett M, Frank JA, Su G, Pespeni M, Angel A, Howard MB, Matthay MA, Pittet JF: Activation of the stress protein response prevents the development of pulmonary edema by inhibiting VEGF cell signaling in a model of lung ischemia-reperfusion injury in rats. FASEB J 2006;20:15191521.

118 Carpenter T, Schomberg S, Steudel W, Ozimek J, Colvin K, Stenmark K, Ivy DD Endothelin B receptor deficiency predisposes to pulmonary edema formation via increased lung vascular endothelial cell growth factor expression. Circ Res 2003;93:456463.

119 Karmpaliotis D, Kosmidou I, Ingenito EP, Hong K, Malhotra A, Sunday ME, Haley KJ: Angiogenic growth factors in the pathophysiology of a murine model of acute lung injury. Am J Physiol Lung Cell Mol Physiol 2002;283:L585-L595.

120 Lange M, Hamahata A, Traber DL, Connelly R, Nakano Y, Traber LD, Schmalstieg FC, Herndon DN, Enkhbaatar P: Pulmonary microvascular hyperpermeability and expression of vascular endothelial growth factor in smoke inhalation- and pneumoniainduced acute lung injury. Burns 2012;38: 1072-1078.

$121 \mathrm{Hu}$ XH, Duan YY, Li Y, Xue ZQ: Early responses of VEGF during acute lung injury induced by seawater immersion after open chest trauma. Respiration 2010;79:490496.

122 Jesmin S, Zaedi S, Islam AM, Sultana SN, Iwashima Y, Wada T, Yamaguchi N, Hiroe M, Gando S: Time-dependent alterations of VEGF and its signaling molecules in acute lung injury in a rat model of sepsis. Inflammation 2012;35:484-500.

123 Gillette MA, Hess DR: Ventilator-induced lung injury and the evolution of lung-protective strategies in acute respiratory distress syndrome. Respir Care 2001;46:130-148.

124 Li LF, Huang CC, Liu YY, Lin HC, Kao KC, Yang CT, Liao SK: Hydroxyethyl starch reduces high stretch ventilation-augmented lung injury via vascular endothelial growth factor. Transl Res 2011;157:293-305.

125 Bellingan GJ:The pulmonary physician in critical care * 6: the pathogenesis of ALI/ARDS Thorax 2002;57:540-546. 
126 Varet J, Douglas SK, Gilmartin L, Medford AR, Bates DO, Harper SJ, Millar AB: VEGF in the lung: a role for novel isoforms. Am J Physiol Lung Cell Mol Physiol 2010; 298:L768-L774.

127 Ou XM, Li WC, Liu DS, Li YP, Wen FQ, Feng YL, Zhang SF, Huang XY, Wang T, Wang K, Wang X, Chen L: VEGFR-2 antagonist SU5416 attenuates bleomycin-induced pulmonary fibrosis in mice. Int Immunopharmacol 2009;9:70-79.

128 Hamada N, Kuwano K, Yamada M, Hagimoto N, Hiasa K, Egashira K, Nakashima N Maeyama T, Yoshimi M, Nakanishi Y: Antivascular endothelial growth factor gene therapy attenuates lung injury and fibrosis in mice. J Immunol 2005;175:1224-1231.

129 Stockmann C, Kerdiles Y, Nomaksteinsky M, Weidemann A, Takeda N, Doedens A, TorresCollado AX, Iruela-Arispe L, Nizet V, Johnson RS: Loss of myeloid cell-derived vascular endothelial growth factor accelerates fibrosis. Proc Natl Acad Sci USA 2010;107:4329-4334.

130 Lee S, Chen TT, Barber CL, Jordan MC, Murdock J, Desai S, Ferrara N, Nagy A, Roos KP, Iruela-Arispe ML: Autocrine VEGF signaling is required for vascular homeostasis. Cell 2007;130:691-703.
131 Abadie Y, Bregeon F, Papazian L, Lange F, Chailley-Heu B, Thomas P, Duvaldestin P, Adnot S, Maitre B, Delclaux C: Decreased VEGF concentration in lung tissue and vascular injury during ARDS. Eur Respir J 2005; 25:139-146.

132 Maniscalco WM, Watkins RH, Finkelstein JN, Campbell MH: Vascular endothelial growth factor mRNA increases in alveolar epithelial cells during recovery from oxygen injury. Am J Respir Cell Mol Biol 1995;13: 377-386.

133 Corne J, Chupp G, Lee CG, Homer RJ, Zhu Z, Chen Q, Ma B, Du Y, Roux F, McArdle J, Waxman AB, Elias JA: IL-13 stimulates vascular endothelial cell growth factor and protects against hyperoxic acute lung injury. J Clin Invest 2000;106:783-791.

$134 \mathrm{He} \mathrm{CH}$, Waxman AB, Lee CG, Link H, Rabach ME, Ma B, Chen Q, Zhu Z, Zhong M, Nakayama K, Nakayama KI, Homer R, Elias JA: Bcl-2-related protein A1 is an endogenous and cytokine-stimulated mediator of cytoprotection in hyperoxic acute lung injury. J Clin Invest 2005;115:1039-1048.

135 Tuder RM, Zhen L, Cho CY, TarasevicieneStewart L, Kasahara Y, Salvemini D, Voelkel NF, Flores SC: Oxidative stress and apoptosis interact and cause emphysema due to vascular endothelial growth factor receptor blockade. Am J Respir Cell Mol Biol 2003;29: 88-97.
36 Sandler A, Gray R, Perry MC, Brahmer J, Schiller JH, Dowlati A, Lilenbaum R, Johnson DH: Paclitaxel-carboplatin alone or with bevacizumab for non-small-cell lung cancer. N Engl J Med 2006;355:2542-2550.

137 Chow LQ, Eckhardt SG: Sunitinib: from rational design to clinical efficacy. J Clin Oncol 2007;25:884-896.

138 Ferrara N, Hillan KJ, Novotny W: Bevacizumab (Avastin), a humanized anti-VEGF monoclonal antibody for cancer therapy. Biochem Biophys Res Commun 2005;333: 328-335.

139 Penn JS, Madan A, Caldwell RB, Bartoli M, Caldwell RW, Hartnett ME: Vascular endothelial growth factor in eye disease. Prog Retin Eye Res 2008;27:331-371.

140 Chen HX, Cleck JN: Adverse effects of anticancer agents that target the VEGF pathway. Nat Rev Clin Oncol 2009;6:465-477.

141 Roth DA, McKirnan MD, Canestrelli I, Gao MH, Dalton N, Lai NC, Roth DM, Hammond HK: Intracoronary delivery of an adenovirus encoding fibroblast growth factor-4 in myocardial ischemia: effect of serum antibodies and previous exposure to adenovirus. Hum Gene Ther 2006;17:230-238. 